\title{
Universitetslärares skrivande om och för sin undervisning
}

\author{
Drivkrafter, stöd och utmaningar
}

\author{
Mona Fjellström och Maria Wester \\ Umeå universitet
}

\begin{abstract}
Syftet med denna artikel är att diskutera förutsättningarna för universitetslärares skrivande om och för sin undervisning. I policydokument och regelverk på såväl nationell som lokal nivå uttrycks förväntningar om att lärare ska problematisera, utforska och dokumentera sin undervisning; förväntningar om ett akademiskt lärarskap. I denna artikel utgår vi från ett case där ett antal lärare beskriver sina tankar om och erfarenheter av att skriva om undervisning. Via enkäter, fokusgruppsintervjuer och kursutvärderingar har vi inhämtat kvantitativa och kvalitativa data från 30 deltagare i en högskolepedagogisk kurs med fokus på skrivande om och för undervisning. Våra data har analyserats innehållsligt utifrån en förståelseinriktad ansats. Resultaten visar att skrivande om och för undervisning försiggår ensamt, osett och i tystnad samtidigt som lärarna upplever stor osäkerhet inför det de upplever som annorlunda skrivande. Baserat på våra resultat presenterar vi förslag på hur högskolelärares skrivande om och för undervisning kan stödjas.
\end{abstract}

Nyckelord: akademiskt skrivande, akademiskt lärarskap, skriva om undervisning, stöd för skrivande.

\section{INLEDNING OCH SYFTE}

Texter är viktiga i det akademiska arbetet. De utgör grunden för ämnesförståelsen, undervisningen, förståelsen av praxis inom såväl forskning som undervisning, de prövande samtalen och kunskapsutvecklingen. Under senare delen av 1900-talet har ett allt större fokus lagts på textproduktion som mått på akademisk produktivitet. Samtidigt har dock lärares beforskande av sin undervisning och läromedelsproduktion fört en tämligen osedd och marginell tillvaro. Detta har skett samtidigt som högre utbildning förändras i en allt snabbare takt med konsekvenser för både ledningsansvariga, lärare och studenter. Några av de förändringar som återkommer i många beskrivningar av utvecklingen är: målstyrd utbildning, massutbildning, heterogena studentgrupper, flexibel utbildning, en nationell och global utbildningsmarknad samt en förändrad ledningskultur (se t ex Barnett, 2000; Geschwind \& Forsberg, 2015 och Kwiek, 2005). I Vetenskapsrådets rapport konstaterar Geschwind och Forsberg att:

Det finns således ett påtagligt behov av att både utveckla och systematisera kunskap som finns om högskolesektorn och dess utveckling och förändringar. Sektorns betydelse för enskilda individer och samhällsutvecklingen liksom dess storlek, komplexitet och förändringstakt motiverar särskilt att forskningen om högre utbildning uppmärksammas. (Geschwind \& Forsberg, 20I5, s 7)

*Författarkontakt: mona.fjellstrom@umu.se

Artiklar och reflektioner är kollegialt granskade. Övriga bidragstyper granskas av redaktionen. Se www.hogreutbildning.se ISSN 2000-7558

(C)2019 Mona Fjellström och Maria Wester. This is an Open Access article distributed under the terms of the Creative Commons Attribution-NonCommercial 4.0 International License (https://creativecommons.org/licenses/by-nc/4.0/), allowing third parties to share their work (copy, distribute, transmit) and to adapt it, under the condition that the authors are given credit, that the work is not used for commercial purposes, and that in the event of reuse or distribution, the terms of this license are made clear.

Citation: Mona Fjellström och Maria Wester (2019) "Universitetslärares skrivande om och för sin undervisning», Högre utbildning, 9(1), 20-33. http://dx.doi.org/10.23865/hu.v9.1063 
Beforskandet av högre utbildning kan förstås som en uppgift enbart för forskare inom pedagogik eller utbildningsvetenskap men vore det så, skulle den forskningen bara synliggöra en avgränsad del av den högre utbildningen. Geschwind och Forsberg beskriver den högre utbildningen som ett "mångfacetterat fält som tar form i skärningspunkten mellan policy, praktik och kunskapen om dessa" (Geschwind \& Forsberg 20I5, s 7). Såväl forskare som lärare i alla högskolans discipliner och utbildningar kan genom att skriva om och för sin utbildningsverklighet såväl synliggöra som förstå den högre utbildningen i all dess komplexitet. Det är heller inte rimligt att tro att vår kunskap om högre utbildning uteslutande kan vila på finansierade forskningsprojekt eller organiserade forskningscentra. Det som behövs är förutsättningar för forskare och lärare att ingå i olika kunskapsproducerande praktiker som är öppna för en mångfald frågeställningar, metodval och diskussioner. Ett sådant synsätt stöds av en alltmer framtonande diskurs kring det akademiska lärarskapet (se t ex Silén \& Bolander Laksov, 20I3; SUHF, 20I7) som har sin grund i texter om Scholarship of Teaching and Learning (SoTL) (Boyer, 1990; Glassick m fl, 1997; Hult, 200I; Kreber, 2007; SUHF, 20I7). Förväntningarna på ett akademiskt lärarskap visar sig idag, om än splittrat och med varierande fokus, på både policy- och organisatorisk nivå i form av kvalitetssystem och kvalitetsgranskningar, formuleringar i anställningsordningar, underlag för sakkunniggranskningar och nya pedagogiska meriteringssystem (ESG, 20I5; Ryegård, 2013; SUHF, 2016; 2017; UKÄ, 2016; Winka, 2017).

Diskursen om ett akademiskt lärarskap kan utifrån ett mer kritiskt förhållningssätt förstås som en del i de performativa strömningar som innebär allt större krav på att granska, utvärdera, redovisa eller på annat sätt visa upp en praktik för andras granskning och maktutövning (se t ex Boshier, 2009). I denna studie har vi dock valt en förståelseinriktad ansats (Ödman, 2007, kap 3). Det innebär att vi ser det akademiska lärarskapet som en väg för lärare att utveckla högre utbildning genom att synliggöra och förstå.

... scholars of teaching and learning explore how to create the vital connection between themselves and the 'subject', themselves and students, and students and the 'subject. This includes developing an informed sense of why particular content areas matter, an understanding of why students may not yet see why these matter, and sensibilities around and skill in helping them understand why they matter. (Kreber, 2007)

Ett akademiskt lärarskap innebär i praktiken att läraren utifrån ett undersökande förhållningssätt till undervisning och lärande samverkar med andra aktörer i undervisningen, genomför, förändrar och utvecklar undervisningen samt offentliggör sin praktik och sina erfarenheter. Det kan handla om praktiknära studier av den undervisning man genomför eller förutsättningarna för den högre utbildningen men också, menar vi, läromedel man utvecklar för att stödja studenternas lärande i ett visst ämne. De dokumenterade erfarenheterna, reflektionen eller det nya läromedlet utgör grunden för de kunskapsutvecklande, kritiskt granskande kollegiala samtal och praxisförändringar som är en viktig förutsättning för utvecklingen av högre utbildning (se t ex Mårtensson, Roxå \& Stensaker, 20I4).

Vid Umeå universitet har det sedan 201 erbjudits en högskolepedagogisk kurs, Att skriva om och för undervisning. Syftet med kursen är att ge lärare stöd för att dokumentera något de studerat i sin undervisning, det vill säga skriva om undervisning, eller för att producera undervisningsmaterial, alltså skriva för undervisning. Kursen, som genomförs över ett läsår med åtta halvdagsträffar och ett tre dagar långt skrivinternat, ger också deltagarna möjlighet att utveckla sitt akademiska skrivande och att meritera sig pedagogiskt. Totalt har fem kurser genomförts, 
och 4I deltagare från många olika discipliner har fullföljt kursen. Deltagarna har sin disciplinära hemvist i till exempel datavetenskap, geografi och ekonomisk historia, pedagogik, språkstudier, statistik, statsvetenskap och teknisk fysik och elektronik. Som lärare på den kursen har vi i möten med kursdeltagarna hamnat i samtal om olika frågor kring förutsättningarna för högskolelärares skrivande om undervisning och i förlängningen det akademiska lärarskapet.

Den fortsatta texten tar sitt avstamp i forskning om akademiskt skrivande. I forskningsöversikten presenteras förståelseramen för den empiriska studien samt grunden för vår diskussion av studiens resultat och våra egna erfarenheter som lärare på kursen.

\section{SKRIVANDE SOM PRAKTIK}

Skrivande är en av akademins grundläggande praktiker och följaktligen finns det en uppsjö läroböcker som handlar om det vetenskapliga skrivandet (Dysthe $\mathrm{m} \mathrm{fl,} \mathrm{20II;} \mathrm{Nyberg} \mathrm{\&} \mathrm{Tidström,}$ 20I2; Widerberg, 2003). Majoriteten riktar sig till studenter och doktorander men det finns exempel på böcker som också riktar sig till högskolelärare och forskare (Murray \& Moore, 2006; Conrad \& Serlin, 20II; Augustsson, 2012 och Sword, 2012 och 20I7).

Återkommande teman i dessa böcker om det akademiska skrivandet är skrivprocessen, språkliga grepp/stil, skrivande som stöd för (sitt eget) lärande samt betydelsen av sociala sammanhang och återkoppling. Samtliga böcker, som riktar sig till den enskilde skribenten eller handledaren, erbjuder en förståelse av skrivandet som ett hantverk och en process med goda råd och förslag på hur man kan arbeta med sitt skrivande. De teman vi finner i läroböckerna återkommer i forskningen om akademiskt skrivande men där vidgas också bilden av det akademiska skrivandet till att inkludera frågor om förutsättningar, drivkrafter och organiserat stöd för att stötta universitetslärares skrivande.

En central utgångspunkt för universitetslärares akademiska skrivande är betydelsen av den egna disciplinens epistemologi och akademiska skrivtraditioner (Murray \& Moore, 2006, kap 4). Under sin tid som student och doktorand skolas man in i en genre som kan uppfattas som en på förhand given del av de sanningsanspråk man har och de metoder man använder. Studier av forskares uppfattningar om det akademiska skrivandet visar (något förenklat) att forskare inom naturvetenskap uppfattar skrivandet som ett rapporterande av fakta medan forskare inom samhällsvetenskap och humaniora ser skrivandet som tolkande och meningsskapande (Erixon, 20II; Graue, 2006). Text producerad i en annan skrivtradition än den egna betraktas ofta som ovetenskaplig och obegriplig utan att man kanske är klar över skillnaderna i genre. I "The handbook of academic writing" (2006) påtalar Murray och Moore vikten av att man utvecklar en förståelse för det specifika i den egna disciplinens skrivande. De skillnader i skrivtraditioner som lyfts fram av dessa författare belyser också hur svårt det kan vara att skriva i en annan skrivtradition än den man är inskolad i.

Trots att skrivande är en av de centrala förmågorna i den akademiska skickligheten så är skolningen in i det akademiska skrivandet oftast informell och oreflekterad. I en longitudinell studie av akademiskt skrivande med I 223 informanter från lärosäten över stora delar av världen kunde Sword visa att endast 15 \% hade någon formell utbildning i akademiskt skrivande (Sword, 20I7). Nära hälften av hennes informanter, $47 \%$ :

[...] had learned to write more or less under their own steam, whether through trial and error, by drawing on past experience, or on the basis of advice and feedback from other people. (Sword, 2017, s 64)

1 Informanterna beskrevs som "academic staff", "postgraduate students", "research fellows and other writers". 
Swords studie ger en bild av skrivandet som en i huvudsak traderad, praktisk och ensam verksamhet.

I en studie av 42 framgångsrika skribenter visade resultaten att förutsättningen för det akademiska skrivandet var att man avskärmade sig såväl fysiskt som socialt och kognitivt från övrig verksamhet vid institutionen (Murray, 2013). Murray, som har gett sin artikel den talande rubriken It's not a hobby: reconceptualizing the place of writing $i$ academic work, drar slutsatsen att detta avskärmande är nödvändigt men svårt att genomföra. Lösningen är att vända på perspektivet och konstruera sitt engagemang för skrivande på fysiska platser vikta för skrivande, i sociala sammanhang och för ökad legitimitet för skrivandet (Keen, 2007; Murray, 20I3).

Det akademiska skrivandet som ursprungligen syftade till spridande av kunskap, kritisk granskning och diskussion har alltmer kommit att påverkas av att publiceringsfrekvens blivit viktigt för finansiering och karriär. Det styr akademiker att dels skriva artiklar före böcker, dels att noggrant läsa av genren så att man får sin artikel antagen av en tidskrift (Hamilton \& Weiner, 20II; Murray \& Moore, 2006). Det har också fört med sig en strävan att publicera sig i högt rankade tidskrifter, vilket få högskolepedagogiska eller ämnesdidaktiska tidskrifter är.

Förväntningarna på att producera publicerad text har också gett upphov i olika stödinsatser för akademiskt skrivande (Lee \& Boud, 2003; Murray, 2008; Murray \& Thow, 20I4). McGrail, Rickard och Jones genomförde en studie där de kunde visa att de vanligaste stödinsatserna för att öka publikationsfrekvensen var skrivargrupper där kollegor läser och kommenterar varandras texter, skrivarkurser eller mentorer (McGrail, Rickard \& Jones, 2006). I vår forskningsgenomgång hittar vi här för första gången texter som inte handlar om akademiskt skrivande generellt utan om aktiviteter som ska stödja akademiskt lärarskap (Marquis, Healey \& Vine, 20I6; Weaver, Robbie \& Radloff, 20I4). Syftet med stödaktiviteterna är ofta att utveckla deltagarnas förmåga att skriva akademiska texter, ge och ta emot återkoppling på text, öka självförtroendet som skribenter och stimulera lusten att fortsätta skriva.

Betydelsen av just ett ökat självförtroende som skribent (och akademiker) och en ökad känsla av lust inför skrivandet har lyfts fram i ett antal studier. Mer än två tredjedelar av Swords informanter beskriver "blandade känslor" inför skrivandet. Många av dem beskrev de negativa upplevelserna med ord som skuld, uppgivenhet, frustration och ångest (Sword, 2017, s 153-155). Hennes studie visade dessutom att kvinnliga doktorander var de som genomgående beskrev mer negativa känslor. Kvinnliga akademikers beskrivning av negativa känslor kopplade till skrivandet, av sig själva som "outsiders" och skrivandet som en del av ett tidvis plågsamt blivande till akademiker har också beskrivits i studier av Grant (2000; 2006) och Aronson \& Swanson (I99I).

Det som framtonar i denna forskningsgenomgång är en komplex inramning av det akademiska skrivandet där många olika faktorer samspelar. Den absoluta majoriteten av dessa texter handlar dock om akademiskt skrivande som en generell akademisk aktivitet eller färdighet. Ytterst få texter tar upp det specifika i att skriva om eller för undervisning och vad det kan innebära för utmaningar för lärare som har utvecklat sitt akademiska skrivande inom en annan disciplin än pedagogik eller utbildningsvetenskap. Detta osynliggörande av skrivande för och om undervisning och i förlängningen av det akademiska lärarskapet väckte många frågor hos oss.

Under 2013 påbörjade vi därför en studie som skulle fördjupa vår förståelse för lärares drivkrafter, behov och utmaningar i skrivandet om undervisning. Det vi ville belysa knöt an till det akademiska lärarskapet och lärares skrivande för att offentliggöra sin praktik och sina erfarenheter för att bidra till kollegiala samtal och praxisutveckling. Studien skulle också utgöra underlag för utveckling av kursen.

Studien är därmed också en del i vårt eget akademiska lärarskap. 


\section{Mona Fjellström och Maria Wester}

Studien utformades för att besvara följande forskningsfrågor:

- Vilka attityder möter lärare som vill skriva om undervisning på sin institution?

- Vilka förutsättningar har de för sitt skrivande om undervisning?

- Vilket stöd vill de ha för sitt skrivande?

- Vad har kursen inneburit för deras skrivande?

Vi har avgränsat vår studie till att inhämta information som belyser universitetslärarnas tankar om och erfarenheter av de egna och institutionens möjligheter och begränsningar.

\section{METOD}

För att få svar på våra frågor har vi, efter genomförda kurser, vänt oss till kursdeltagarna från fem kurser, totalt 4I universitetslärare. Samtliga informanter informerades om att de deltog i en studie, syftet med studien, att alla data skulle behandlas konfidentiellt samt att de kunde avbryta sitt deltagande när som helst.

Med en förståelseinriktad ansats har vi fokuserat på kvalitativa data med några få kvantitativa basdata som komplement (Ödman, 2007). Insamlingen av kvalitativ empiri har genomförts i två olika faser med delvis olika metoder. I den första fasen, då vi samlat in data från de tre första kurserna, ombads kursdeltagarna först att besvara en kursutvärdering $i$ form av en webbenkät. Avsikten med denna var att få en överblick över kursdeltagarnas tankar och erfarenheter. Kursutvärderingen besvarades av 19 lärare. Med utgångspunkt i svaren från enkäten genomfördes sedan två fördjupande fokusintervjuer. Deltagare från de tre första kurserna tillfrågades via e-post om de ville delta i en fokusintervju. Sex kursdeltagare deltog i två fokusgrupper med 3 deltagare vid varje. Fokusintervjuer användes för att i samtalsform kunna dra fördel av deltagarnas interaktion i synliggörandet av olika tankar och perspektiv (Carey \& Asbury, 20I2, s I7). På detta sätt kan också tidigare outtalade tankar synliggöras (Farnsworth \& Boon, 20IO, s 6II).

Med erfarenheterna från första datainsamlingsfasen som grund genomfördes sedan under fas två datainsamlingen enbart via kursutvärderingar. Dessa kursutvärderingar besvarades av I2 kursdeltagare, varav en inte slutfört kursen och därför räknats bort. Frågorna i fas tvås kursutvärderingar var bearbetade så att de skulle fånga in information som kompletterade och fördjupade de data som inhämtats i fas I. Utformningen av fas två baserades bland annat på svårigheterna att samla kursdeltagarna till fokusintervjuer.

\section{RESULTAT OCH ANALYS}

Fokusgruppsintervjuerna har transkriberats och analyserats tillsammans med resultaten från kursutvärderingarna. Den kvalitativa innehållsanalysen har inriktats på att synliggöra bärande teman och eventuella kontraster i informanternas utsagor.

Totalt deltog 30 informanter i studien, 20 kvinnor och Io män. Det totala antalet som genomfört kursen är 26 kvinnor och I5 män. Av de 30 har I9 (63\%) svarat på frågan om hur länge de arbetat i akademin. Knappt hälften $(47 \%)$ av de som svarat har jobbat som högskolelärare i mer än sex år och några (2I \%) mer än femton år. Deltagarna var alltså att betrakta som erfarna lärare och akademiska skribenter. I de två fokusintervjuerna deltog totalt 5 kvinnor och I man.

\section{ETT POSITIVT VAKUUM}

Lärarna i vår undersökning beskriver i huvudsak två attityder gentemot skrivande om och för undervisning. Den ena attityden är en allmänt positiv inställning till skrivande överhuvudtaget, undervisning likaväl som om forskning. Den frihet över den egna arbetstiden som åtminstone 
delvis finns inom akademin möjliggör också undervisningsskrivande. Att skriva om undervisning som del av ett akademiskt lärarskap är dock inget som initieras eller aktivt stöds från institutionsledningen. En informant säger:

eftersom man styr över sin tid är det ingen som säger att man inte gör det heller, ingen säger att du får inte göra det där, du måste göra det här. (Fokusintervju I)

Den andra attityden, som de flesta beskriver, innebär att det är skrivande om forskning som är prioriterat:

Så skriva om undervisningen det fanns inte på kartan. Utan det var så att all KU-tid ska användas till att meritera sig vetenskapligt. [...] skulle man gjort det så var det att: jojo, nog kan det vara bra, men du får göra det på din fritid eller klämma in det någonstans, inte något som direkt uppmuntrades. (Fokusintervju I)

Talet om skrivande i undervisning handlar i stort sett uteslutande om att producera undervisningsmaterial. En informant beskriver att på dennes institution så finns överhuvudtaget ingen kunskap om att det går att skriva om undervisning: "det är som att ja men, vad gör du på riktigt då, vad forskar du om?” (Fokusgrupp 2). Det är dock få informanter som beskriver att de möter öppet motstånd mot att skriva om undervisning.

När det väl producerats artiklar/konferenspresentationer, så kan lärarna mötas av en positiv reaktion från ledningen. En informant berättar att efter hon fått en artikel om undervisning accepterad, så bad prefekten henne hålla ett lunchseminarium, som också prefekten deltog i. Detta var inte vanligt när någon vid institutionen fått en vetenskaplig artikel accepterad, utan speglade det ovanliga $\mathrm{i}$ att någon faktiskt fătt en artikel om undervisning publicerad. En annan informant berättar att prefekten inte visste någonting vare sig om skrivarkursen eller om att skriva om undervisning, men när hen såg resultatet för kursdeltagaren - det blev en artikel och ett seminarium på institutionen - så anmälde sig prefekten till skrivarkursen året därpå. Dock är det endast en informant som beskriver sin studierektor som en person som uppmuntrar lärarna att skriva, att gå högskolepedagogiska kurser och att visa arbete med kursutveckling.

Frånvaron av ledningsstöd eller konkreta förväntningar om ett akademiskt lärarskap bidrar till lärarnas osäkerhet inför att skriva om undervisning.

OSÄKERHETEN - Är det jag gör av värde och intresse för andra? Den inre ”Feeling like a fraud"-känslan pockar på hela tiden ... (Enkätsvar 2)

Flera av informanterna ger uttryck för att de deltagit i kursen och skrivit av eget intresse och inte för att undervisningsskrivande har ett värde inom akademin:

om du inte skickar in den [forsknings-]ansökan så, i mitt fall, förminskas min chans att finnas kvar vid universitetet ganska radikalt, men om jag skriver den där artikeln inom undervisning så kanske det inte spelar så stor roll. (Fokusintervju 2)

Ramfaktorer inverkar påtagligt på universitetslärares skrivande om och för undervisning. De krympande resurserna för undervisning innebär, tillsammans med kraven på vetenskaplig meritering för att kunna göra karriär, att ett akademiskt lärarskap prioriteras ner i den enskilde lärarens balansgång mellan undervisning, forskning och samverkan. Dessutom prioriteras skrivande 
om ämnesforskning över skrivande om och för undervisning. I vår studie beskrivs tid som den mest betydelsefulla faktorn när det gäller undervisningsskrivande (Åström, 2008). Vår tolkning är dock att detta snarast är en konsekvens av att det inte efterfrågas eller finns utrymme för ett akademiskt lärarskap på institutionerna. Det visar sig i den vänliga likgiltighet eller milt positiva, till intet förpliktigande, inställning till skrivande om undervisning som framträder i våra resultat.

\section{ENSAMHET PÅ SIDAN OM}

Majoriteten av informanterna skrev ensamma. Det berodde som regel på att det saknades kollegiala miljöer där undervisningen diskuterades som gemensamma aktiviteter. Informanterna upplevde sig ensamma med sin undervisning, sina frågor och skrivambitioner.

[...] det ändå är en minoritet som börjat skriva om sin undervisning, den stora majoriteten tycker sig inte ha så mycket att ställa frågor om, de är inte så insatta, [...] så det är ungefär som om man skulle vara ensam på ett forskningsfält nästan, och det är därför man inte får så mycket feedback. (Fokusintervju I)

Förutsättningarna för att kunna skriva om undervisning handlar också om fysisk arbetsmiljö. De flesta i undersökningen uppger att de kan sitta och skriva på jobbet. De som inte kan det, framför allt för att de i så fall blir störda, sitter hemma.

Informanterna berättar att de behöver tid, helst i längre sjok om minst en vecka, men även heldagar skulle innebära helt andra möjligheter än vad de oftast har idag. I intervjuerna beskriver några hur de försöker skriva en timme här och en timme där, vilket någon säger kan fungera när texten börjat ta form, men inte inledningsvis. En annan berättar att eftersom området är nytt för henne, blir det ännu viktigare med obruten skrivtid.

[...] jag tyckte det var enklast att göra det under sommaren så att jag kunde få ett sjok med tid och sitta och göra det [...] men skriver jag på en artikel i [mitt ämne] då kan jag skriva en timme och sen gå iväg och göra annat och sen komma tillbaka, för då är det ju samma hjärna jag använder. (Fokusintervju 2)

Någon talar om det egna motståndet för att den här typen av skrivande är både svårt och ovant. En informant föreslår att "man borde boka tid med sig själv" (Fokusintervju I). En av informanterna berättade att hen anmälde sig till kursen för att söka stöd i form av att tvinga sig själv till att avsätta tid. Att hitta en samarbetspartner beskrivs som en framkomlig väg och ibland rent av en nödvändig förutsättning;

Jag tror ju att vi skulle få så oändligt mycket mer publicerat om vi samarbetade mer med folk [...] Det är ju samma sak som vi gör i vår forskning, jag ger mig väl inte in i något alldeles nytt utan att plocka med mig någon annan forskare. (Fokusintervju 2)

Utan en kollegial miljö där undervisningsfrågor är av gemensamt intresse är det mycket svårt att få och ta sig tid till denna typ av skrivande. Delvis kopplas det till traditionen på institutionen, där seniora kollegor, framför allt professorer, inte skriver om eller för undervisning. Resultatet blir att undervisningsskrivande uppfattas som något avvikande från normen som hamnar långt ner på att-göra-listan.

[Det har] låg status på institutionen. Det gör inget på det känslomässiga planet men det skapar en viss ensamhet. (Enkätsvar I) 


\section{PÅ OKÄNDA VÄGAR}

För de flesta informanterna innebar undervisningsskrivandet att de gav sig ut på okända vägar. Även om de inledningsvis hade tänkt att detta nog inte var så svårt så ställdes de inför stora utmaningar då varken den genomförda studien eller skrivandet följde den vetenskapliga norm de var inskolade i. Etablerade arbetssätt och förståelser ställdes på huvudet med resultatet att lärarna inte visste hur de skulle gå vidare.

Informanterna berättar också om upptäckten av att inse vad som behövs för att genomföra ett skrivprojekt av denna typ, att inse sina egna förmågor och begränsningar.

Det finns flera aspekter i det här, dels då att man underskattar hur svårt det är att skriva, man tycker att man bara snor ihop något så blir det en artikel, man tycker ja, det gör vi, superenkelt. [...] men sen när man då ska göra det på riktigt, så är det ju inte, då måste man byta hjärninställning, man måste som gå från naturvetenskap till samhällsvetenskap. Och det är då inte så busenkelt som man tror. (Fokusintervju 2)

I enkäten beskriver de att de behöver verktyg för att kunna skriva om och för undervisning, men framför allt kunskap om samhällsvetenskapliga metoder och det pedagogiska språket.

Bara det här att läsa pedagogiska artiklar, det tar ju också tid när man inte är van att läsa sådana, och liksom hitta, vad är det viktiga och vad ska jag bygga vidare på. Det tar ju också mycket tid och där behövde jag verkligen få fatt och fokusera på det och skriva samtidigt som jag läste, det var ganska mycket. (Fokusintervju 2)

Språkgranskning, med fokus på både innehåll och form, samt feedback var stöd som efterfrågades av flera informanter. De berättade dock också om svårigheterna att tolka feedbacken när den väl kom.

[...] så skickade jag in den under sommaren och så kom den tillbaka med jättemycket reviewkommentarer, och då skickade jag den till [henne] och skrev: hjälp, jag förstår ingenting. (Fokusintervju 2)

Det samlade intrycket är att lärarna befann sig i samma situation som nya studenter. De behärskade inte de vetenskapliga grundantaganden som är utgångspunkten för en studie av undervisning. Inte heller behärskade de språket eller kunde arbetsmetoderna. Trots sina akademiska kunskaper och erfarenheter fick de jobba hårdare och med fler utmaningar än de förväntat sig.

\section{ATT MÖTA ANDRA}

Flera av våra informanter berättade att de hade sökt sig till kursen för att få träffa andra som ville skriva om undervisning och som ett sätt att komma igång med ett skrivprojekt de länge funderat på. Att upptäcka kursinbjudan väckte tankar om att undervisningsskrivande kanske var möjligt. I ett fall ledde det också till att informanten i förväg tog kontakt med en kollega för att höra om hon ville haka på.

A: Så mailade jag till [henne] och sa att du, ska vi? Och då ville ju du det, så det var nog så att jag hade inte någon stor drivkraft innan, utan det var mer att det blir ju bra det här i den pedagogiska meriteringen, det blir något annat än vad andra har. Något mer dokumenterat. B: Jo, när du sa att du skulle gå den, då hängde jag också på. (Fokusintervju 2) 
Att söka kursen var också ett sätt att söka sig till en ny praxisgemenskap (community of practice; Wenger, 1998), att knyta nya professionella kontakter och göra sig synlig på ett fält som man var intresserad av.

Att man faktiskt kan skriva om det, att det liksom funkar att göra en artikel av det här projektet, och så förhoppningsvis få det publicerat. Att någon läser och blir litet inspirerad - så skulle jag kunna göra också. (Fokusintervju I)

En informant beskriver en önskan att ha någon form av långtidsstruktur och vi pratar i det fokussamtalet om ett universitetsövergripande nätverk där "man kan ha seminarier, presentera ett utkast eller läst något" (Fokusintervju I).

Att i kursens organiserade former möta andra lärare som var intresserade av och arbetade med undervisningsskrivande var inspirerande. Möjligheten att på jämbördig nivå få ta del av andras skrivarmödor och få konstruktiva kommentarer på sin egen text lyftes fram som en av de riktigt värdefulla erfarenheterna.

Man får jättemycket ut av att [möta kollegor från andra ämnen]. Man förstår ju mer hur det uppfattas det man har skrivit, eller hur man kan uppfatta andra saker, eller hur man skulle vilja att man skrev själv. (Fokusintervju I)

\section{SJÄLVINSIKTER OCH FRAMTIDSUTSIKTER}

Så kommer vi till frågan om vad kursen har inneburit för dem. I såväl enkät som i intervju beskriver kursdeltagarna att de fått ökat självförtroende och känner sig stärkta av skrivarbetet tillsammans med andra. Undervisningsskrivandet har visat sig ha betydelse för fler än dem själva och liksom i studien av Weaver $\mathrm{m} f$ dessutom visat sig vara en rejäl akademisk utmaning

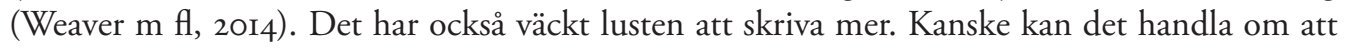
detta annorlunda skrivande ger utrymme för tankar och språkliga valörer som inte finns i det egna ämnet.

Jag känner mig också ganska stolt att jag har fått ihop till en artikel som är någorlunda bra, vi får väl se om den är tillräckligt bra för att bli publicerad. Men i alla fall känns det som att jag faktiskt lyckats åstadkomma något av allt det här och som förhoppningsvis kan vara till nytta, så jag tycker nog det känns som att det har gett mig mycket, jag tycker egentligen det är ganska roligt att skriva. (Fokusintervju 2)

Informanterna berättar också om att de haft nytta av arbetet under kursen i andra sammanhang, till exempel i arbetet med UKÄ:s utvärderingar (självvärderingar) eller sin egen undervisning. Att under skrivandet behöva redogöra för utgångspunkter, antaganden, sammanhang och resultat har synliggjort undervisningen som en vetenskapligt grundad praktik. De nya frågorna och svaren väcker både nyfikenhet och en utvecklad beredskap för olika undervisningssituationer.

Jag har fått en djupare förståelse kring de teorier som finns för lärande, och reflekterat över mig själv och min egen roll i en lärandeprocess. (Enkätsvar 8)

Några planerar att fortsätta hålla kontakt, antingen som kritiska vänner i fortsatt skrivande eller som samarbetspartners. Enstaka inslag nämns också, och gemensamt för varför de nämns är att de varit ögonöppnande på något sätt. Ett exempel på detta är det pass som handlade om olika 
traditioner/skolor inom vetenskapligt skrivande, där den samhällsvetenskapliga och naturvetenskapliga traditionen förklarades.

[...] en sak som hjälpte mig jättemycket var den här föreläsningen ni hade om, vad ska man säga, naturvetenskapligt och samhällsvetenskapligt arbetssätt. Även om den var väldigt generaliserande, så hjälpte den mig att få ord på det här främlingskapet som jag på något sätt kände inför texten. Jag visste inte riktigt hur jag skulle hantera den. Och efter den där föreläsningen så blev det så tydligt för mig varför jag kände så, eftersom jag är så inskolad i naturvetenskapligt tänkesätt, där man gör sina experiment och sen så rapporterar man det i texten. Och i för sig så skriver man ju där också, man måste skriva så man förklarar, men i en samhällsvetenskaplig text där är det liksom så att experimentet är i texten. (Fokusintervju 2)

Även själva skrivandet har fått en ny innebörd. En person beskriver ett konkret förhållningssätt som utvecklats under kursen:

Skrivandet är som toppen på ett isberg, det är som en process som är under ytan som är så mycket större, man börjar tänka och tankarna far, jag har börjat nu att skriva mer löpande anteckningar och då klarnar det mer. (Fokusintervju 2)

\section{SLUTSATSER OCH DISKUSSION}

Trots de försvårande omständigheter som beskrivits i denna artikel, så väljer ett antal universitetslärare att skriva om och för undervisning. Det kan tyckas förvånande med tanke på den tämligen dystra bakgrund vi målat upp. De skriver trots att de flesta i bästa fall möts av vänlig likgiltighet och trots att det inte gynnar deras akademiska karriär. De skriver i ensamhet och till stor del på sin fritid för att det saknas kollegiala forum för att diskutera utbildningsskrivande och för att forskning i ämnet är prioriterat. De skriver om och för undervisning trots att detta skrivande för många innebär stora utmaningar både innehållsligt och stilistiskt.

Orsakerna till att lärarna skriver är flera - $\mathrm{i}$ vårt material framträder ett intresse för undervisning, en lust att dela med sig och fördjupa sina kunskaper tillsammans med andra samt en stolthet över sin lärarkompetens som centrala utgångspunkter. Detta innebär att det med största sannolikhet finns en stor outnyttjad potential vid vårt universitet - och antagligen vid andra för såväl läromedelsproduktion som beforskande och utveckling av högskolepedagogik. Frågan som infinner sig är hur denna potential kan tas tillvara.

På många punkter bekräftar denna studie andra forskares resultat men den har också visat att ett akademiskt lärarskap innebär nya och komplexa skrivutmaningar även för erfarna akademiska skribenter. Bara för att man disputerat $\mathrm{i}$ ett ämne så har man inte med automatik de färdigheter som behövs för att skriva om undervisning. Allra helst inte om skolningen i vetenskapligt skrivande skett genom "trial and error" och tradering. Lärarna behöver stöd eller åtminstone utforskande samtal med andra för att kunna göra det epistemologiska och stilistiska kliv som behövs.

De lärare vi träffat är de som i enlighet med Murrays tankar sökt sig till sociala sammanhang där undervisningsskrivande är legitimt och med fysiska platser vikta för skrivandet (Murray, 20I3). I denna miljö har de, kanske för första gången, fått möjlighet att tillsammans med andra intresserade kollegor diskutera det akademiska skrivandet som hantverk, process och del i ett lärarskap i förändring. För dessa lärare erbjöds en möjlighet till skrivarstöd via en högskolepedagogisk kurs som sträckte sig över ett läsår. Det kan få fart på en skrivprocess och kanske leda till en publikation men det som behövs är att universiteten konkret börjar efterfråga och satsa 
på akademiskt lärarskap som en del i arbetet med att kontinuerligt förändra och kvalitetssäkra utbildningarna. Pedagogiskt ansvariga på institutions- och fakultetsnivå kan tillskapa mötesplatser för lärare som är intresserade av utbildningsfrågor och vill skriva om det de möter i sin undervisning. Kanske kan de alltfler pedagogiskt meriterade vid våra lärosäten få uppgiften att, i samverkan med en högskolepedagogisk enhet, stödja och uppmärksamma lärares lust att skriva om och för sin undervisning. Att ge lärare möjligheter att skriva om och för sin undervisning skulle ta tillvara lärares erfarenheter och utveckla ny kunskap samt också ge alla lärarkategorier möjlighet att publicera och meritera sig. De skulle också kunna få uppmärksamhet och uppskattning för ett arbete som blir alltmer utmanande. Sverige skulle också kunna bli en mer synlig samtalspartner i samtalet om högre utbildning på internationell nivå. Vi har mycket att bidra med inte minst genom att besvara viktiga frågor om hur ett akademiskt lärarskap kan stödjas och vad det ger den högre utbildningen.

Avslutningsvis vill vi rikta ett varmt tack till de informanter som deltog i studien och generöst delade med sig av sina tankar och erfarenheter.

\section{EPILOG}

Under vårt arbete med denna studie får vi höra talas om att några deltagare (från olika ämnen) på kursen tagit eget initiativ till att fortsätta träffas efter kursen för att stödja varandras skrivande. De har nu träffats regelbundet för att stötta varandras skrivande i mer än tre år. Inledningsvis träffades de ett par gånger per termin men glädjen i och utbytet av träffarna har gjort att de nu träffas en gång per månad och avsätter mer tid, en hel dag, för att skriva och kommentera varandras texter.

\section{FÖRFATTARPRESENTATION}

Mona Fjellström är disputerad i pedagogik och universitetslektor på Universitetspedagogik och lärandestöd vid Umeå universitet. Hennes forskning fokuserar högskolepedagogiskt utvecklingsarbete på olika nivåer inom akademin. Hon undervisar på högskolepedagogiska kurser, ingår i Educational advisory board vid två universitet och medverkar i olika uppdrag för SUHF, UKÄ och FINEEC.

Maria Wester är universitetslektor i pedagogiskt arbete och arbetar på Universitetspedagogik och lärandestöd vid Umeå universitet. Hennes forskningsintresse ligger inom det högskolepedagogiska fältet och har ett särskilt fokus på makt- och genusaspekter samt högskoledidaktik. Hon undervisar bland annat på högskolepedagogiska kurser och på Rektorsprogrammet.

\section{REFERENSER}

Aronson, A. \& Swanson, D. (1991) Graduate Women on the Brink: Writing as “Outsiders Within”. Women's Studies Quarterly, 19(3/4) 156-173.

Augustsson, G. (2012) Akademisk skribent: om att utveckla sitt akademiska skrivande. Lund: Studentlitteratur. Barnett, R. (2000) Realizing the University. Buckingham: SRHE and Open University Press.

Boshier, R. (2009) Why is the Scholarship of Teaching and Learning such a hard sell?, Higher Education Research \& Development, 28(1) 1-15.

Boyer, E. L. (1990) Scholarship reconsidered: Priorities of the professoriate. Princeton: The Carnegie Foundation for the Advancement of Teaching.

Carey M. A. \& Asbury J. (2012) Focus group research. Walnut Creek, CA: Left Coast Press.

Conrad, C. \& Serlin, R. (2011) (eds) The Sage Handbook for Research in Education. Engaging Ideas and Enriching Inquiry, Section IV: Writing, Voicing and Disseminating Research. Thousand Oaks, London: Sage Publications.

Dysthe, O., Hertzberg F. \& Lökensgard Hoel, T. (2011) Skriva för att lära. Lund: Studentlitteratur. 
Erixon, P-O. (2011) Academic literacies; Discourse and Epistemology in a Swedish University. Education Inquiry, 2(2) 221-238.

European Association for Quality Assurance in Higher Education (ENQA) (2015) Standards and Guidelines for Quality Assurance in the European Higher Education Area (ESG).

Farnsworth, J. \& Boon, B. (2010) Analysing group dynamics within the focus group. Qualitative Research, $10(5) 605-624$.

Geschwind, L. \& Forsberg, E. (2015) Forskning om högre utbildning - aktörer, miljöer och teman. Stockholm: Vetenskapsrådet.

Glassick, C., Huber, M., \& Maeroff, G. (1997) Scholarship assessed: Evaluation of the professoriate. San Francisco, CA: Jossey Bass.

Grant, B. (2000) Flights of imagination: Academic women be(com)ing writers. International Journal for Academic Development, 5(1) 6-19.

Grant, B. (2006) Writing in the company of other women: exceeding the boundaries. Studies in Higher Education, 31(4) 483-495.

Graue, B. (2006) Writing in Education Research. In Clifton F. Conrad \& Ronald C. Serlin (eds.) The Sage Handbook for Research in Education. Engaging Ideas and Enriching Inquiry. Thousand Oaks, London: Sage Publications, pp. 515-528.

Hamilton, D. \& Weiner, G. (2011) Dancing at the Edge: Writing for the Academic Marketplace. Education Inquiry, 2(2) 251-262.

Hult, H. (2001) Forskningsprocessen som metafor för undervisning. CUL rapport nr 2. Linköpings Universitet.

Keen, A. (2007) Writing for publication: Pressures, barriers and support strategies. Nurse Education Today, $27(5) 382-388$.

Kreber, C. (2007). What's it really about? The Scholarship of Teaching and Learning as an Authentic Practice. International Journal for the Scholarship of Teaching and Learning, 1(1) 1-4.

Kwiek, M. (2005) The University and the State in a Global Age: renegotiating the traditional social contract. European Educational Research Journal, 4(4) 324-341.

Lee, A. \& Boud, D. (2003) Writing groups, change and academic identity: research development as local practice. Studies in Higher Education, 28(2) 187-200.

Marquis, E., Healey, M. \& Vine, M. (2016) Fostering collaborative teaching and learning scholarship through an international writing group initiative, Higher Education Research \& Development, 35(3) 531-544.

McGrail, M., Rickard, C. \& Jones, R. (2006) Publish or perish: a systematic review of interventions to increase academic publication rates. Higher Education Research \& Development, 25(1) 19-35.

Murray, R. (2008) Innovations, activities and principles for supporting academics' writing. I Moore, s. (red) Supporting academic writing among students and academics. SEDA Special 24. London: Staff and Educational Development Association Ltd.

Murray, R. (2013). 'It's not a hobby': reconceptualizing the place of writing in academic work. Higher Education, 66(1) 79-91.

Murray, R. \& Moore, S. (2006) The handbook of academic writing. A fresh approach. Maidenhead: Open University Press \& McGraw-Hill.

Murray, R. \& Thow, M. (2014) Peer-formativity: a framework for academic writing. Higher Education Research \& Development, 33(6) 1166-1179.

Mårtensson, K., Roxå, T. \& Stensaker, B. (2014) From quality assurance to quality practices: an investigation of strong microcultures in teaching and learning. Studies in Higher Education, 39(4) 534-545.

Nyberg, R \& Tidström, A. (2012) (red) Skriv vetenskapliga uppsatser, examensarbeten och avhandlingar. Lund: Studentlitteratur.

Ryegård, Å. (2013) Inventering av pedagogiska karriärvägar på Sveriges högskolor och universitet, PILrapport 2013:04. Göteborgs universitet.

Silén, C. \& Bolander Laksov, K. (2013) Att skapa pedagogiska möten i medicin och vård. Lund: Studentlitteratur.

SUHF (2016) Mål för behörighetsgivande högskolepedagogisk utbildning samt ömsesidigt erkännande. Rek 2016-1. Stockholm: Sveriges universitets- och högskoleförbund. 
SUHF (2017) Högskolepedagogisk utbildning och pedagogisk meritering som grund för det akademiska lärarskapet. Stockholm: Sveriges universitets- och högskoleförbund.

Sword, H. (2012) Stylish academic writing. Cambridge, MA: Harvard University Press.

Sword, H. (2017) Air \& Light \& Time \& Space. How successful academics write. MA: Harvard University Press.

UKÄ (2016) Vägledning för granskning av lärosätenas kvalitetssäkringsarbete. Pilotstudie. Stockholm: Universitetskanslersämbetet.

Weaver, D., Robbie, D. \& Radloff, A. (2014) Demystifying the publication process - a structured writing program to facilitate dissemination of teaching and learning scholarship. International Journal for Academic Development, 19(3) 212-225.

Wenger, E. (1998) Communities of practice: Learning, Meaning and identity. Cambridge: Cambridge University Press.

Widerberg, K. (2003) Vetenskapligt skrivande. Lund: Studentlitteratur.

Winka, K. (2017) Kartläggning av pedagogiska meriteringsmodeller vid Sveriges högskolor och universitet, PIL-rapport 2017:02. Göteborgs universitet.

Åström, E. (2008) Frihetens pris - ett gränslöst arbete. En tematisk studie av de akademiska lärarnas och institutionsledarnas arbetssituation, Rapport 2008:22 R. Högskoleverket.

Ödman, P-J. (2007) Tolkning, forståelse, vetande. Hermeneutik i teori och praktik. Stockholm: Norstedts.

BILAGA I

Frägor $i$ kursutvärderingen fas 1 (Samtliga med fritextsvar)

I. Har du skrivit något om och/eller för undervisning tidigare? Om du svarade ja på förra frågan, vad har du skrivit?

2. Vad ingår i planen för din KU-tid?

3. Hur skulle du beskriva attityden till att skriva läromedel eller artiklar om undervisning på din institution?

4. Vilken faktisk möjlighet har du att skriva om och/eller för undervisning under arbetstid (vardagar mellan 8-I7)?

5. Kan du sitta på din arbetsplats på universitetet och skriva? Om du svarade nej på den förra frågan, var skriver du?

6. Vilka var dina motiv för att söka kursen Att skriva om och för undervisning?

7. Vilken betydelse har kursen haft för ditt skrivande om och/eller för undervisning?

Frågor i fokusintervjun (Som togs i den ordning samtalet öppnade för)

- Varför vill du skriva om undervisning?

- I enkäten svarar de flesta att attityden till att skriva om undervisning är positiv eller "likgiltig” på hemmainstitutionen. Vi vill gärna höra mer om vad det innebär för er.

- Vilka förutsättningar, kunskaper och/eller kompetenser skulle ni önska för att kunna fortsätta skrivandet om undervisning?

- Vad hindrar eller hotar ditt skrivande om undervisning?

- Hur går ni till väga för att skapa plats (tid/rum/socialt/kognitivt) för att skriva om undervisning?

Tilläggsfrågor:

- Vad har kursen inneburit för ditt skrivande?

- Vad gjorde du under kursen som du inte gör annars?

- Vad får du ut av ditt skrivande? 
Frågor $i$ kursutvärderingen fas 2 (fråga 1-10 med fasta svarsalternativ i en 5-gradig skala från Instämmer inte alls till Instämmer helt. Fräga 11-14 med fritextsvar)

I. Kursen har utvecklat min förmåga att skriva om och för undervisning

2. Det har känts som bortkastad tid att delta i kursen

3. Det är angeläget att skriva om och för undervisning i min lärarroll

4. Kursen har gett mig goda möjligheter att diskutera skrivande med andra kursdeltagare

5. Mina möjligheter att delta fullt ut i kursen har starkt begränsats av andra åtaganden

6. Kursen har varit ett värdefullt stöd i mitt skrivprojekt

7. Utbildningen har utvecklat min förmåga att reflektera över vad som är kvalitet i skrivande

8. Jag hade behövt en introduktion till forskningsmetodik i utbildning

9. Jag kan tänka mig att skriva mer om och för undervisning

Io. Jag har bra stöd för mitt skrivande på institutionen

II. Vad fungerade väl? Vad var det som var givande och varför var det det?

I2. Vad kan ändras och varför?

13. Vad får du ut av att skriva om och för undervisning?

I4. Vad är största hindret för ditt skrivande om och för undervisning? 